\title{
Malin Malmström* and Anna Öqvist Constructing an Entrepreneurial Identity: How Enterprise Intentions Among Young People are Motivationally Formed
}

\author{
https://doi.org/10.1515/erj-2017-0165
}

Received September 26, 2017; accepted July 4, 2021

\begin{abstract}
As enterprise education plays a larger role in schools and young individuals increasingly become the target of entrepreneurial and enterprise policy initiatives, there is a growing need to understand how entrepreneurial intentions can be fostered. This study builds on analyses of interviews with young potential entrepreneurs and their young counterparts, delving more deeply into the identity construction that motivates some individuals, but not others, to develop entrepreneurial identities and enterprise intentions. The findings outline two contrasting routes to identity construction, shedding light on how enterprise intentions are motivationally embedded and providing details on the microfoundations of identity formation that shape these identities and intentions toward enterprise activity.
\end{abstract}

Keywords: case study, constructing identity, enterprise intentions, entrepreneurial identity

\section{Introduction}

Developed countries worldwide recognize the importance of small businesses for creating innovation, new employment opportunities, and economic growth (Tohmo and Storhammar 2019). Nevertheless, entrepreneurial activity worldwide has been reported to be lowest among individuals under 25 years old, and Swedish youth are no exception. Among young individuals, the Global Entrepreneurship Monitor (GEM) reported entrepreneurial intentions in Sweden to be $8.5 \%$, representing a 10-year decline, with nascent entrepreneurship rates reaching only $4.9 \%$ (GEM 2014). However, the GEM also reports that $51.6 \%$ of young individuals in Sweden - one of the largest percentages in the world - consider entrepreneurship

*Corresponding author: Malin Malmström, Luleå University of Technology, Luleå, Sweden, E-mail: malin.malmstrom@ltu.se

Anna Öqvist, Luleå University of Technology, Luleå, Sweden

๖ Open Access. @ 2021 Malin Malmström and Anna Öqvist, published by De Gruyter. (c) BY work is licensed under the Creative Commons Attribution 4.0 International License. 
to be a desirable career choice. Only Germany and Malaysia have equally high levels (GEM 2014). Hence, the number of potential entrepreneurs among young individuals in Sweden is surprisingly high, suggesting that young individuals represent an unexploited source of new business start-ups and economic growth. Although individuals may wait before embarking on an entrepreneurial journey, statistics indicate that potential entrepreneurs exhibit an early and persistent interest in business venturing. We have, for instance, learned from previous studies that adult career expectations and intentions begin to form during the teen years among college-bound students (e.g. Low et al. 2005). Pre-entrepreneurial phenomena, such as deciding to embark on an entrepreneurial career, are important in understanding how entrepreneurship can be fostered (Bird 1988) and nascent ventures being "stillborn" can be avoided (Krueger and Brazeal 1994; Reynolds 1994).

Governments worldwide are increasingly attempting to unlock this potential resource represented by young individuals; however, their targeted efforts have produced varying results (Hytti and O'Gorman 2004). To improve policy, it is important to gain an understanding of the formation of entrepreneurial activity that takes place before observable action (Hsu, Shinnar, and Powell 2014). Then, more effective steps can be taken to encourage enterprising activity by fostering beliefs favorable to entrepreneurship (Beugelsdijk 2007; Kautonen, Tornikoski, and Kibler 2011; Linan and Chen 2009).

Nascency is a state in which a venture exists as a potential future that is "in the process of emergence" (Karlsson and Williams-Middleton 2015, p. 469) within the imagination of the founding entrepreneur. Before nascency, entrepreneurship may lay latent within certain individuals, who represent potential entrepreneurs (Krueger and Brazeal 1994). As Fisher, Kotha, and Lahiri (2016) note, at this stage, the identity of the entrepreneurial venture is essentially embedded in the identity of the entrepreneur's self. Entrepreneurial activity is, thus, expected to be anchored in the entrepreneur's personal identity, which is formed and arises from an individual's relationship with existing norms and motivations (Deephouse and Suchman 2008; Owens, Robinson, and Smith-Lovin 2010). Individuals who form their identities in accordance with normative expectations can be seen as following a general "perception or assumption that the actions of an entity are desirable, proper, or appropriate within some socially constructed system of norms, beliefs, and definitions" (Suchman 1995: 574). An entrepreneurial roleidentity is the character that individuals devise for themselves as entrepreneurs, including the "imaginative view of oneself as she/he likes to think of her/himself being and acting" as an entrepreneur (McCall and Simmons 1966, p. 67). Entrepreneurial identity, therefore, is defined as "the constellation of claims around the founders, organization and market opportunity of an entrepreneurial entity that 
gives meaning to the questions of 'who we are' and 'what we do'” (Navis and Glynn 2011, p. 480). This “constellation of claims” produces a sense of self as a potential or non-potential entrepreneur (Fisher, Kotha, and Lahiri 2016). However, we lack clear insight into the foundations of such (non-)entrepreneurial identities. To address this shortcoming, the present article will focus on why some individuals, but not others, may seek to become entrepreneurs by addressing the following research question: how are entrepreneurial/non-entrepreneurial identities motivationally formed? The decision to become an entrepreneur may reasonably be considered to be voluntary and conscious (Krueger, Reilly, and Carsrud 2000), and motivational differences influence the likelihood of entering into entrepreneurial processes (Barba-Sánchez and Atienza-Sahuquillo 2017; Shane and Venkataraman 2000). Accordingly, it seems reasonable to analyze how such a decision comes about, that is, how young individuals form or do not form identities as entrepreneurs. Specifically, we explore how individuals, as proxies for potential ventures, form entrepreneur/non-entrepreneur identities (Deephouse and Suchman 2008; Uberbacher 2014).

Our study makes the following contributions to existing knowledge. First, it adds to the entrepreneurship literature by focusing on the currently underresearched dimension of how identities are embedded during the pre-action phase of the entrepreneurial process. Research on the earliest stage of entrepreneurial activity and how young individuals undertake identity work to achieve legitimacy for themselves and their proposed ventures in the context of normative expectations is currently lacking, and this study seeks to address this gap. Second, we show that, although reality is a social construction, it has real consequences and social effects. We also demonstrate how this reality frames young individuals' perceptions of their career choices, which provides behavioural direction. By conceptualizing the micro-foundations of (non-)entrepreneurial identity and improving our understanding of how identities are embedded in established social norms, we contribute new conceptualizations with which to understand identity construction. This contributes to new knowledge regarding how entrepreneurial identities are embedded. Researchers have also highlighted the importance of cognitive variables in understanding personal decisions, such the decision to become an entrepreneur (e.g. Baron 2004; Shaver and Scott 1991). Although we have gained important insight into the emergence of entrepreneurship from previous studies drawing on theory of planned behavior, we have recently learned that self-identity has proven to be a stronger predictor of founding intentions, even above and beyond the effect of the TPB variables (Obschonka et al. 2015). Therefore, we adopt a cognitive approach and draw upon social identity theory, which has the potential to offer important insights into the complex process of entrepreneurship. The study also contributes to the discussion of the role of social 
expectations in entrepreneurial cognition processes (see, e.g. Mitchell et al. 2007). We also contribute to the knowledge gap regarding the development and origins of entrepreneurship-related identities (Obschonka et al. 2015). Third, implications for policy and actors developing entrepreneurship support can be derived because the study provides more detailed information about how individuals form their identities and which micro-foundations motivate their entrepreneurial identities and intentions toward enterprise activity.

\section{Entrepreneurial Intentions and Cogntive Antecedents}

When attempting to understand the emergence of entrepreneurship, which is rare, obscure, and potentially linked to unpredictable time lags, intentions have proven particularly valuable (MacMillan and Katz 1992). In the entrepreneurial context, intentions are defined as individuals' convictions to intend to start new ventures and conscious plans to open businesses at some future point in time (Thompson 2009). A growing body of literature posits that intentions play a significant role in the launch of new businesses (e.g. Kolvereid 1996; Krueger and Carsrud 1993; van Gelderen et al. 2008) and that intentions to start a business are the first step in the business formation process (Lee and Wong 2004). Existing research has shown that intentions predict behavior (Ajzen 1987, 1991), and empirical analyses of entrepreneurial intentions are increasingly common (Autio et al. 2001; Fayolle, Gailly, and Lassas-Clerc 2006; Kickul and Zaper 2000; Kolvereid and Isaksen 2006; Lee and Wong 2004; Peterman and Kennedy 2003; Veciana, Aponte, and Urbano 2005; Zhao, Hills, and Siebert 2005). Because entrepreneurship may be viewed as a process that occurs over time (Gartner et al. 1994; Kyrö and Carrier 2005), entrepreneurial intentions can be considered the first step in the evolving and sometimes lengthy process of venture creation (Lee and Wong 2004). The intention to start a business, then, is a necessary precursor to the performance of entrepreneurial behaviors (Fayolle, Gailly, and Lassas-Clerc 2006; Kolvereid 1996b). Prior research has also demonstrated that cognitive factors, such as entrepreneurial selfefficacy and self-confidence, are essential cognitive states needed to succeed in creating a business and play a key role in sparking individuals' interest in pursuing entrepreneurial careers. Although a growing body of research has explored this issue, there is still a need to better understand what fosters entrepreneurial intentions.

In another vein of research, Shepherd, Douglas and Shepherd (2000) argue that individuals seek to make utility-maximizing career choices. In other words, 
individuals will choose to be self-employed if the total utility they expect to derive from entrepreneurship is greater than the total utility they expect to derive from their best employment option (see also Douglas and Shepherd 2000; Gifford 1993). However, it remains unclear how individuals come to this conclusion regarding utility. In other words, to understand where enterprise intentions come from, we must further understand the antecedents of intention and, in particular, the cognitive variables influencing intention and prompting individuals to develop entrepreneurial intentions. By taking a cognitive approach, this article aims to build on the small but growing body of literature suggesting that entrepreneurial activities are infused with meaning because they express individuals' identities (Cardon et al. 2009; Hoang and Gimeno 2010a).

\section{Social Identity Theory and Entrepreneurship}

A general notion is that cognitions drive most behavior, such as acting in accordance with one's identity. Accordingly, it is difficult to imagine starting a business in which the potential venture is launched merely as a conditioned response to a stimulus because founding a business typically reflect the founder's self-image in relation to entrepreneurship. It is just as difficult not to view starting a venture as a career choice. Previous research suggests that career decisions are not responses to stimuli but are clearly anchored within self-beliefs and intentional in nature, reflecting cognitive processing. Accordingly, career choices reflect cognitive processes in which beliefs and intentions evolve as we cognitively process and form our identities (Lent, Brown, and Hackett 1994), and the process of engaging in entrepreneurship can be regarded as intentionally driven due to the strong relationships between intentions and actual behavior (Sheppard, Hartwick, and Warshaw 1988).

Identities emerge from the beliefs and perceptions individuals have about themselves in relation to particular phenomena, such as entrepreneurship. Specifically, identities are constructed when individuals relate their self-perceptions to positive or negative beliefs that certain behaviors will produce favorable or unfavorable outcomes (Sveningsson and Alvesson 2003; Ybema et al. 2009). Individuals thereby orient themselves on the basis of attributes, values, "true stories," and norms (Ashforth and Mael 1989; Tajfel and Turner 1979) and develop self-images in relation to lifestyles, tastes, and practices (Tajfel and Turner 1979). Logically, then, we can expect that the more an individual perceives that starting a business will have a positive outcome, the more favorable his or her entrepreneurial identity construction - and, therefore, expected intention to found an enterprise - will be. In other words, the constant questions "Who am I?" and "How 
do I fit (into desired and valued social groups)?” are rooted in individuals' concept of self and need to find their own place in society (Leitch and Harrison 2016; Mead 1934; Tajfel and Turner 1986; Ybema et al. 2009). This iterative and dynamic relationship requires dedicated identity work to bridge the gap between who we are, who we can be, and who we need/want to be during daily life (Gioia et al. 2013; Marlow and McAdam 2015). To date, research on an entrepreneur's identity has investigated different role identities in and outside the entrepreneurial process (Murnieks and Mosakowski 2007a, 2007b), the change from an employee role to an entrepreneurial role (Hoang and Gimeno 2010a, 2010b), and the role of passion in entrepreneurship (Cardon et al. 2009). Further, research on the effects of identity on entrepreneurship focuses primarily on the level of the firm. For instance, Whetten and Mackey (2002) suggest a link between an entrepreneurial identity and working in specific types of firms. They argue that identity claims are embedded in norms about the definition of appropriate and meaningful identities. Further, in an emerging firm, an entrepreneur's identity has been suggested to be relatively strong (Chroneer, Johansson, and Malmstrom 2015; Deephouse and Suchman 2008) because firm decisions are often made by a single person (the entrepreneur) and emerging firms are typically small entities that have yet to be shaped. Entrepreneurial identity has been linked to passion and behaviour (Murnieks and Mosakowski 2007a, 2007b) and ethnic identity (Ireland and Webb 2007). Further, entrepreneurial identity has been found to vary because individuals are likely to differ in how they orient themselves to the entrepreneur role (Hoang and Gimeno 2010b; Verheul, Uhlaner, and Thurik 2005). Nevertheless, there is little empirical evidence to substantiate these notions or provide systematic insights into how individuals' identities are motivationally embedded and shape enterprise intentions. Although more research is needed on entrepreneurial identity conceptions, it is likely that differences in individuals' role conceptions relate to their different experiences and relations with those being entrepreneurs (Ozgen and Baron 2007) and how entrepreneurs are portrayed in such individuals' social contexts (Dodd 2002; Steyaert and Katz 2004).

Although founders of ventures likely have commercial ambitions, entrepreneurship is viewed as an inherently social activity, and identities are anchored in socially constructed value systems (Fauchart and Gruber 2011). These social aspects of the entrepreneurial self-concept are likely important in entrepreneurship because venture creation is an inherently social activity and ventures are, themselves, social constructions. Social norms may, therefore, inhibit individuals from realizing their intentions to become entrepreneurs. From a motivational perspective, motivational differences may influence the likelihood of entering entrepreneurial processes (Barba-Sánchez and Atienza-Sahuquillo 2017). Motivational differences have been linked to necessity and opportunity, as well as to 
variations in traits among individuals. For instance, variations in individuals' perceptions of risk and opportunity have been found to influence entrepreneurial decisions (Shane and Venkataraman 2000). Nevertheless, this stream of research has broadly overlooked that motivation may influence specific steps in the entrepreneurial process differently (Shane, Locke, and Collins 2003), and we lack insights into the early motivations that form individuals' self-identity in terms of an entrepreneurial career (Hsu, Shinnar, and Powell 2014). Taken together, the above review supports the idea that examining young individuals' identity construction can improve our understanding of the characteristics of educated, enterprising individuals and how their identities are motivationally embedded. In this study, we explore the roots of an entrepreneurial/non-entrepreneurial identity in early adulthood and, thereby, aim to contribute to an increased understanding of how an entrepreneurial identity does/does not become a part of an individual's occupational self-concept.

\section{Research Methodology}

The study of enterprise/non-enterprise intentions inherently examines entrepreneurial phenomena before a venture has actually been founded and, consequently, includes currently non-entrepreneurial subjects. For this reason, students are often used as a relevant sample in such studies because they can share their vocational preferences at a time when they are facing actual career decisions (Krueger, Reilly, and Carsrud 2000). Indeed, students can be characterized as "between things," a state that is often associated with a higher likelihood of starting a new venture (Shapero and Sokol 1982). Accordingly, we collected our data from a sample of Swedish high school individuals who were about to enter work life and whose career aspirations were first taking form. The sampled students were at a point in their education when they were making pivotal career choices by choosing educational profiles and exerting educational efforts in school.

\subsection{Data Collection and Analyses}

We build our findings primarily on narrative data, which have been demonstrated to be useful in understanding and interpreting behavior (Gabriel 2000). However, the subjective nature of narratives presents challenges when attempting to objectively examine behaviors. As a consequence, this study also uses survey data to identify enterprise intensions, to base our interview sample on, and complement 
the narratives. This combination allowed us to first identify enterprise intentions and then achieve a deeper understanding of what lies behind these intentions, that is, the micro-foundations of an entrepreneurial/non-entrepreneurial identity.

Our findings build on interview data with 16 individuals identified within a larger sample of 993 graduating Swedish high school students (483 women and 509 men; response rate $=74 \%$ ) who filled out a questionnaire. The questionnaire consisted of Likert-type scales developed based on existing measurements (Chandler and Lyon 2001). The survey analyses made it possible to detail two primary types of enterprise intentions among young individuals. We used a composite of two measurements to identify two groups of students with high and low intentions of starting and running their own businesses. These measurements of enterprise intensions were as follows: "How likely is it that you will have founded your own business within five years of graduation?" and "How likely is it that you will ever found your own business ?” on 7-point Likert scales ranging from $1=$ not likely at all to $7=$ highly likely (Chronbach's alpha $=0.855)$. Using this composite, we identified eight individuals for interviews in the high (four women and four men with the highest scores) and low (four women and four men with the lowest scores) quartiles who could be classified as potential entrepreneurs or not. During the analysis of the narratives, we used these two typologies as categories for the initial classification.

\subsubsection{Design and Sampling - Qualitative Data}

To conduct the interviews, this study used a case design to capture the cognitive mechanisms that may influence young individuals' perceptions of starting and owning businesses (Eisenhardt 1989; Hallen and Eisenhardt 2012). Here, we focused on young individuals' identity construction and corresponding action within a social context. Using these data, we aimed to improve the understanding of the heterogeneity in meanings that young individuals associate with their potential entrepreneurial endeavors, as well as the effects of such heterogeneity on career choices. We developed an interview guide to support the individually conducted interviews in capturing and qualifying the students' experiences (see Appendix 1). The questions were developed based on social identity theory and aimed to capture young individuals' concept of self in terms of future career choices and the literature on how individuals orient and view themselves in relation to entrepreneurship (Leitch and Harrison 2016; Tajfel and Turner 1979; Ybema et al. 2009). The interviews were recorded and transcribed to increase our ability to identify fragmented and complex patterns in the narratives reflecting constructions of entrepreneurship and shed light on how identities are formed with regard to enterprise intentions (cf. Mezias and Scarselletta 1994). 


\subsubsection{Data Analysis - Qualitative}

As recommended in the methodological literature on qualitative research, we performed a content analysis of the collected data. This analysis allowed us to capture how entrepreneurship is approached and looked upon among young individuals and how socially constructed identities may enable or disable entrepreneurial engagement (Krippendorff 2012). We used a social constructionist view to analyse young individuals' identity constructions (Berger and Luckmann 1966) because different individuals may experience different "truths" concerning what a career as an entrepreneur means and may associate entrepreneurship with different contexts and experiences. Such social constructions are produced and made real through the identity work by which these individuals construct their realities (cf. Mumby and Clair 1997). Such identity work is expected to mould young individuals' identities in certain directions.

This work was guided by an established three-step procedure. Appendix 2 and Figure 1 present the coding, coding structure, and resulting categories. First, statements in the interview material were initially identified through coding. This step involved the identification of statements that related to reasoning, explanations, and positions taken regarding entrepreneurship. The coding was inspired by a micro-analysis strategy suggested by Strauss and Corbin (1990), in which accounts and phrases in the material were scanned (Glaser and Strauss 1967). The classification was inductively elicited and not based on a priori hypotheses. We coded the material individually and held meetings to match our individual coding. In doing so, we noticed very high consistency and began to identify a discourse related to identity construction. In this process, we used Nvivo software to crossrun and support our coding.

Next, a conceptualization process was undertaken to conceptualize the statements regarding entrepreneurship. The first-order conceptualization included three sub-steps. A micro-analysis approach was followed, as outlined by Strauss and Corbin (1990), by engaging in a line-by-line examination of the text for the purpose of generating central themes, identifying the relationships among these themes, and developing an understanding of the studied phenomenon. In conducting the micro-analysis, we scanned and searched for statements and expressions associated with a set of guiding questions. Example questions included the following: (1) What were the perceptions of entrepreneurship? (2) what experiences of entrepreneurship were there? and (3) what were the rationales for their reasoning about entrepreneurship? Such guiding questions enabled a balance between richness and direction (Miles and Huberman 1994).

Second, as the coding proceeded, Nvivo software was used to categorize the identified concepts into types of perceptions (Miles and Huberman 1994). This 
approach aimed to address the reliability of the data analysis (Eisenhardt and Graebner 2007; Miles and Huberman 1994). The respondents' narratives of entrepreneurship were used to crystallize the statistical findings. The results of the narratives were relevant to creating a deep understanding of the statistical results concerning how young individuals may construct their images of entrepreneurship, which impact their preparedness to engage in entrepreneurship.

The analysis of the interview data identified 20 major themes, or microfoundations. It became evident that the 16 interviewed individuals constructed two distinctly different identities that clearly positioned them as either potential entrepreneurs or not. We began to see that the emergent themes were present in both identity constructions but with distinctly different characters. We noticed that variations in the micro-foundations caused patterns of identity formation among the constructions. Given the consistency of the patterns observed across the cases, we were able to clearly categorize all 16 students into one or the other of the two profiles.

During the second-order conceptualization, the patterns were reviewed, the coded material was grouped into categories, and overarching themes were identified. As we engaged in this process, we noticed that the content could be understood by social identity theory and that the coding could be collapsed into categories (Tajfel and Turner 1979). We used Miles and Huberman's (1994) categorization approach to identify similarities in the coding. When reviewing the patterns, we began to look for relationships. We noticed that the potential and non-potential typologies had multiple shapes and driving forces, and we used these to distinguish the patterns and reveal distinct relationships suitable for theorizing.

Further, we coded the narratives associated with the potential and nonpotential entrepreneurs and identified four discriminatory identity formation routes with contrasting constructions: (1) Self-determination in work life versus Well-being in work life; (2) Jam tomorrow versus Jam today; (3) Self-reliance in managing the downsides of entrepreneurship versus Self-doubt about controlling the downsides of entrepreneurship; and (4) Self-confidence in managing resource acquisition versus Self-doubt about the ability to manage resource acquisition. The findings based on this coding and analysis process revealed that enterprise intentions appeared to be a consequence of the dominant identity work to entrepreneurship. To illustrate this finding and ensure construct validity, we present narrative stories and quotes. This was done to secure construct validity. We also compared our emergent theoretical framework with the extant literature to refine our construct definitions, abstraction levels, and theoretical relationships (Eisenhardt and Graebner 2007). The extant literature was especially useful in sharpening the underlying logical arguments. Based on the lens of social identity 
theory, our theoretical conceptualization offers insights into how an entrepreneurial identity becomes or does not become rooted among young individuals. The identified theoretical concepts and patterns were derived from an interpretive process. Iterations between inductive conceptualization and the literature supported the sharpening of construct definitions and the identification of patterns among the categories (Eisenhardt and Graebner 2007).

\section{Findings}

The different ways in which the individuals imbue entrepreneurship with meaning were conceptualized by depicting the micro-foundations of two contrasting identity constructions outlining how entrepreneurial and non-entrepreneurial identities are motivationally embedded. Four discriminatory routes to identity formation provide insights into what underlies the identity construction of each profile, which illuminate the characteristics and various identity. Our findings reveal how potential entrepreneurs imbue entrepreneurship with meaning by reinforcing positive formation routes of entrepreneurship, while those who were not potential entrepreneurs undermine the same by reinforcing negative formation routes, building on micro-foundations. We noticed that the potential entrepreneurs constructed entrepreneurship based on the following micro-foundations: a path to independence, a desire to gain control over their work life, a belief in their likelihood of earning superior future compensation, and a belief in their ability to manage the potential downsides of entrepreneurship and gain access to necessary resources. This induced meaning of an identity aligning with being an entrepreneur. By contrast, those who were non-potential entrepreneurs constructed identities that distanced them from entrepreneurship. These individuals enforced their counter-position by emphasizing the importance of well-being in their work life, which they believed conflicted with being an entrepreneur; felt that superior compensation would come from employment; expressed a belief in their inability to manage the potential downsides of entrepreneurship; and noted their lack of access to the resources necessary to embark on an entrepreneurial journey.

We review these contrasting viewpoints and probe their potential to cast light on individuals' identity construction with regard to entrepreneurship in more detail below. Specifically, we show that the individuals constructed their identities by inducing meaning through four discriminatory identity formation routes. Our findings revealed the use of ten micro-foundations to induce meaning in identity formation. These micro-foundations were used to activate beliefs that reinforced or undermined their identities as entrepreneurs. Detailed representative statements for each micro-foundation are depicted in Appendix 2 and illustrated in Figure 1. 


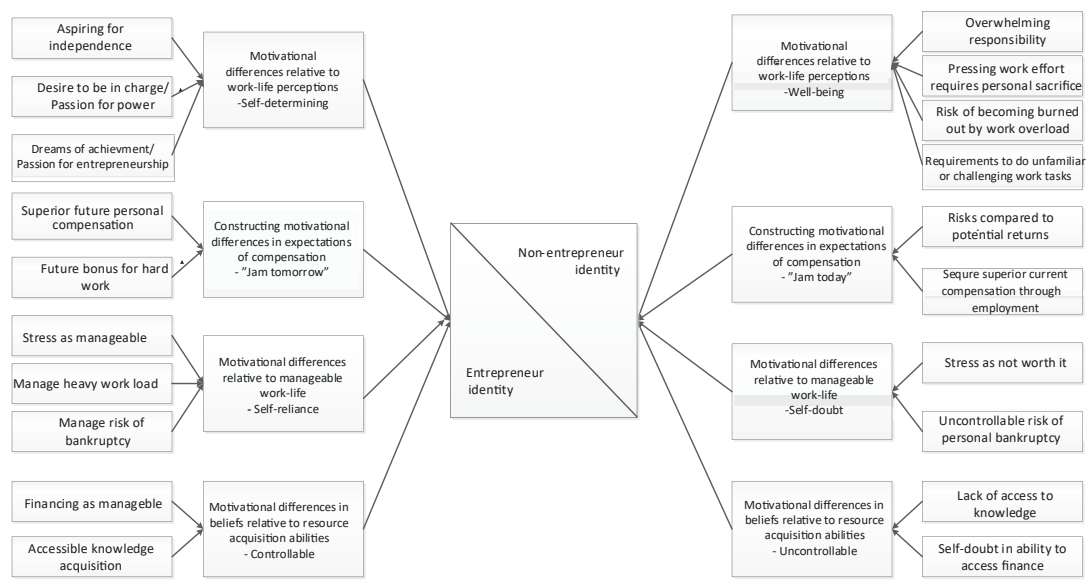

Figure 1: Discriminatory identity formation routes for emerging entrepreneurial/nonentrepreneurial identity.

\subsection{Potential Entrepreneurs: Motivational Differences Relative to Work-Life Perceptions}

The identity construction on the part of potential entrepreneurs regarding how they associate themselves with entrepreneurship clearly highlights how they posit themselves as being a part of the "in-group" in relation to an identity as an entrepreneur. The first discriminatory identity formation route relates to identifying what is important in work life. The theme used by potential entrepreneurs to construct their identity as aligning with entrepreneurial characteristics focused on the importance of being self-determining in one's work life and inducing meaning of self-determining through entrepreneurship. Entrepreneurship thus offers them an arena in which they can achieve such self-determination by exploring their passion for building something on their own, being in charge, and being independent. These micro-foundations were embedded in the identity of being an entrepreneur and the act of entrepreneurship itself, as presented below.

'Aspire for independence': To construct self-determination through entrepreneurship, meaning was induced through an aspiration to be independent and avoid others' influence on one's daily work. Their constructions commonly emphasized a preference for choosing their own ways of working, as expressed by statements such as: "I can decide for myself how to conduct my work. It's all under my own control. That is a driving force for me to own and run my own business" (for additional example statements for each micro-foundation, see Appendix 2). 
'Desire to be in charge-Passion for power': Meaning was induced through a desire to be in charge, to be one's own boss, as well as a passion for achieving power. Example expressions included "There are almost only advantages to starting my own business. Taking charge and deciding everything is very appealing."

'Dream of achievement-Passion for entrepreneurship': Meaning was also induced through passion, interest, and following a dream. Expressions indicating that starting a business was something they were passionate about and that they found appealing, fun, and exciting also align with characteristics of being an entrepreneur. Example statements included "Developing products is a dream for me, something I have always been interested in. I have always found it appealing to invent new things." These micro-foundations show how they constructed their identities around self-determination in their work life.

\subsection{Non-Potential Entrepreneurs: Motivational Differences Relative to Work-Life Perceptions}

While potential entrepreneurs constructed their views of what was important in work life around self-determination, non-potential entrepreneurs constructed theirs around well-being. This different reasoning added to undermine aspects of entrepreneurship while reinforcing the positive aspects of career choices as being an employee. The constructions used by non-potential entrepreneurs to portray entrepreneurship clearly highlighted how they positioned themselves as part of the "out-group" with respect to an identity as an entrepreneur. In terms of microfoundations, they argued that entrepreneurship requires too much of them in terms of responsibility, work effort, and sacrifice and that the risks are too high given the potential returns. They realized that such reasoning may constrain their future financial position, but they reasoned that they would at least retain control of their well-being. Thus, they distanced themselves from an entrepreneurial identity and, instead, constructed their identities in a direction oriented toward employment and rooted in the importance of well-being in work life. They positioned entrepreneurship in contrast to well-being. Entrepreneurship was constructed as involving too much responsibility, requiring extensive work effort, and scarifying, which would promote a high level of stress.

'Overwhelming responsibility': In those constructing an identity distant from an entrepreneurial identity, meaning was induced through the perspective that being an entrepreneur means overwhelming responsibility. They expressed such sentiments as, "There would be a lot of pressure on you. It could be tough, since everything depends on you," which present entrepreneurship as non-desirable. 
Instead, they reasoned that being employed would offer a slower working pace and require less responsibility, which they perceived as important for maintaining well-being. Example expressions included, "Being employed also means a slower work pace and that I don't need to be responsible for making all the money."

'Pressing work efforts require personal sacrifice': Meaning was induced by the belief that being an entrepreneur required pressing work effort and the personal sacrifice of one's spare time, which was considered a deterrent and risk to their well-being in terms of work life. Such perspectives facilitated the construction of a non-entrepreneurial identity. Example expressions included "You won't have any time left for anything but work, work, work".

'Risk of becoming burned out by work overload': By considering entrepreneurship to be a health risk, such as the risk getting 'burned out' by work overload, entrepreneurship was considered undesirable. Simultaneously, employment was constructed as a way to avoid such health risks. Example statements about entrepreneurship included: "I think it means a heavy overload of things to do all the time. I think it is quite nice to just be employed by someone else.” Some referred to stories of entrepreneurship as unhealthy, recounting: "I have heard about entrepreneurs who had their own businesses who got burned out, and I don't want to end up like that."

'Requirements to do unfamiliar or challenging work tasks': The challenge of being required to do things they were not good at was used to position entrepreneurship as discouraging and off-putting. Example expressions included "I want to do what I am good at, what I am educated to do, and not a bunch of other things." They expressed a conviction that entrepreneurship requires work outside an individual's scope of interest and competence. These micro-foundations show how identities were constructed around well-being in work life.

\subsection{Potential Entrepreneurs: Constructing Motivational Differences in Expectations of Compensation}

The second discriminatory identity formation route involved constructing an identity based on expectations of compensation. The theme used by potential entrepreneurs to construct their identities involved the possibility of superior future compensation. Based on this possibility, they formed their identities around the notion that entrepreneurship offers economic "jam tomorrow," meaning that they envisioned entrepreneurship would give them opportunities to earn the kinds of financial returns that would not be possible through employment. 
'Superior future personal compensation': Entrepreneurship was constructed as a kind of entrepreneurial philosophy: an investment offering opportunities for supreme financial returns on the exploitation of ideas. The conviction of superior compensation manifested in a belief that entrepreneurship would produce superior future personal compensations. Example expressions included "I can earn a lot of money if I start my own business."

'Future bonus for hard work': Meaning was also induced via a conscious patient by expressing awareness that there may be a delay before earning superior compensation and that there is a need for endurance and the willingness to persist to accomplish such superior compensation. Example expressions included "I might not earn a lot of money until I have a good product. It may be a tough job; I will not make money until the product begins to sell well." These microfoundations show how they constructed their identities based on expectations of future superior compensation.

\subsection{Non-Potential Entrepreneurs: Constructing Motivational Differences in Expectations of Compensation}

By contrast, non-potential entrepreneurs view entrepreneurship in the light of alternative career choices, such as employment, and envision the latter to offer a more secure economic future and avoid the risks of foregone compensation inherent in entrepreneurship. The non-potential entrepreneurs used the idea of superior current compensation to construct their identities, emphasizing the notion of economic "jam today" through employment and highlighting the risks of entrepreneurship in comparison with its potential returns. Thereby, employment was constructed as the springboard to supreme financial returns.

'Secure superior compensation through employment': Meaning was formed via beliefs that entrepreneurship is something that could pose a risk an individual's personal financial status and that superior current compensation can be secured through employment. This was emphasized by a skeptical view of the compensation available through entrepreneurship, which they positioned in light of the belief that employment would provide them superior and secure compensation and solid present-day personal finances. Example statements included "You could earn a lot of money running your own business, but that is no guarantee. Instead, I will get a good job in the mining industry and earn good money. It is safe, and you know you have a job.”

'Risks compared to potential returns': Meaning was induced via the belief that the risks of entrepreneurship (e.g. financial, relational, and time-related) are too 
great in comparison with the potential returns. Example expressions included "Even if you actually earn a lot of money running your own business, it should be worth what you need to sacrifice." Instead, the desire to secure traditional employment was used as a rationale, as evident in such expressions such as "If you want to be a boss, you can do that anyway if you are employed and make good money." These micro-foundations show how they constructed their identities based on superior current compensation.

\subsection{Potential Entrepreneurs: Motivational Differences Relative to a Manageable Work-Life}

The third discriminatory identity formation route relates to a manageable work-life situation. The potential entrepreneurs constructed their view of a manageable work life as one in which they were in control of and able to manage the potential downsides of entrepreneurship. Meaning was induced through three microfoundations: stress as manageable, a heavy work load as manageable, and the risk of bankruptcy as manageable, which indicates their self-reliance in terms of managing the potential downsides of entrepreneurship. They expressed a belief in their ability to control the potential "costs" in terms of work overload, stress, and personal bankruptcy and could predict ways to limit these "costs."

'Stress as manageable': Meaning was induced through the belief that they possessed the abilities necessary to manage and control the stress of entrepreneurship. Example expressions included "It's a great responsibility to make sure that the business runs as it should, to take care of personnel, to make the business evolve, handle the financial aspects of the business ... and that might be stressful, but I believe I can control it.” Such expressions illustrate a belief in being able to control the stress of entrepreneurship.

'Heavy work load as manageable': Meaning was also induced by building on a belief in their own ability to manage a heavy work load. Example expressions included "I will probably always think about work and that will likely cost cognitive efforts and risk occupying a lot of energy, but I will be able to manage that."

'Risk of bankruptcy as manageable': Meaning was further induced through a conviction of ability to manage the risks of bankruptcy, specifically a belief that being realistic would help in managing the risks of bankruptcy. Example expressions included "It is important to be realistic and to consider the consequences." Furthermore, employment was positioned as a no more certain economic choice than becoming an entrepreneur through such expressions as 
"I want to run my own business because you are not sure to have a job if you work for someone else, either." These micro-foundations show how they inducing meaning by considering the potential downsides of entrepreneurship to be manageable

\subsection{Non-Potential Entrepreneurs: Motivational Differences Relative to Manageable Work-Life}

In contrast, belief in one's inability to control the potential downsides of entrepreneurship was used to construct a non-entrepreneurial identity. Belief in being powerless to manage downsides and the belief that the potential downsides of entrepreneurship were not manageable were used to induce a non-entrepreneurial identity. The micro-foundations of believing that the overwhelming risk of personal bankruptcy and stress contributed to the construction of a nonentrepreneurial identity.

'Stress is not worth it': Meaning was induced through a belief in the importance of well-being and the micro-foundation that the stress of engaging in entrepreneurship was not worth the potential returns. Entrepreneurship was posited as entering a stressful work life, while employment was considered a way to avoid stress. Entrepreneurship was envisioned as involving long and stressful work days, with participants using expressions such as "It may be stressful; it means a heavy load of work 24/7. I might not be able to have holidays like ordinary people who are employed." These example expressions show how an identity was constructed around the importance of being able to control one's work life and avoid the stress considered inherent in entrepreneurship.

'Uncontrollable risk of personal bankruptcy': By emphasizing such risks as going bankrupt and losing personal financial status, the non-potential entrepreneurs positioned entrepreneurship as an endeavor outside of their control. Constructing an identity around these beliefs helped rationalize the avoidance of entrepreneurship. Example expressions included "The risk of bankruptcy really puts me off. I think it is quite nice to just be employed by someone else." Such example expressions show a conviction that the risk of bankruptcy is unmanageable, and they were used to construct the non-entrepreneurial identities. These micro-foundations show how they induce meaning via self-doubt regarding the ability to overcome the potential downsides of entrepreneurship. 


\subsection{Potential Entrepreneurs: Motivational Differences in Beliefs Relative to Resource Acquisition Abilities}

The fourth discriminatory identity formation route relates to a focus on the resource obstacles to or resource solutions needed for entrepreneurship. Potential entrepreneurs constructed their identities around how to they would acquire the resources necessary for their entrepreneurial endeavors. They described their abilities to control resource acquisition and envisioned how they would overcome current resource constraints through acquiring knowledge of how to start and run a business and how to finance the business. In so doing, they imbued access to resources with meaning by building on the micro-foundations of accessible knowledge acquisition and accessible financing.

'Accessible knowledge acquisition': Despite the awareness that more knowledge of how to start and run a business may be needed to succeed, the identities was constructed around confidence in their ability to manage resource acquisition, and such knowledge was considered to be within their reach. They typically expressed certainty regarding how to gain access to the necessary knowledge through such expressions as "I just need to learn how to run a business and how to make it a success, so I will take a course in running a business." Such convictions build on beliefs that gaining access to necessary knowledge is relatively easy and controllable, as evidenced through expressions such as "I need this knowledge, but it should be relatively easy to get it. I know who to turn to."

'Financing as manageable': Meaning was also induced through the belief that access to financial capital, a pivotal resource, is controllable. This construction positioned finance as an obstacle to overcome but one that was manageable. Example expressions included "I believe in my idea and will try to get the money that I need. I think I can get investment money from my customers; otherwise, I will find someone else who can invest in my business and become part owner of my business.”

\subsection{Non-Potential Entrepreneurs: Motivational Differences in Beliefs Relative to Resource Acquisition Abilities}

Non-potential entrepreneurs constructed their identities around their inability to overcome resource current obstacles. They induced meaning by expressing selfdoubt regarding their ability to master resource acquisition and related such difficulties to entering entrepreneurship, envisioning knowledge and finances as obstacles outside of their control. As such, the micro-foundations used to build an 
identity referred to their current resource shortcomings in terms of knowledge and access to finance which were considered difficult or even impossible to overcome.

'Lack of access to knowledge': When forming their identities, they rooted their beliefs in the idea that necessary knowledge was unattainable by focusing on their current lack of access to knowledge and the difficulties involved in acquiring such knowledge. Example expressions included "There is a lot that I would have needed to learn, and it is all up to me to learn it, and I would not be able to manage that."

'Self-doubt about ability to access finances': By building on self-doubt with regard to their ability to acquire financing and other tangible resources, they induced meaning in their identity construction. Example expressions included "I don't think that I could get the funding for it. I mean, how would I be able to get someone to invest?" These example expressions show the construction of an identity around a conviction that access to finances was unachievable, thus distancing such an identity from entrepreneurship. These micro-foundations show how they induced meaning via self-doubt regarding their ability to overcome the potential downsides of entrepreneurship. All the micro-foundations identified above show identity construction work resulting in two divergent identities, potential entrepreneur or non-potential entrepreneur.

\section{Discussion}

We present a detailed and comprehensive framework of how an entrepreneurial identity is cognitively rooted in beliefs, a framework that covers and goes beyond previous research on entrepreneurship. Our study shows that social context may induce a number of ways of thinking, experiencing, and acting in relation to entrepreneurship, while simultaneously excluding other ways of doing so. Our findings offer insights into the heterogeneity of meanings that young individuals associate with their career choices and potential entrepreneurial endeavors (Hogg and Terry 2000; Tajfel and Turner 1979). Overall, the findings demonstrate that the same entrepreneurial attribute may evoke different values and beliefs, which either undermine or reinforce identity formation as an entrepreneur. The values and beliefs that potential entrepreneurs assign to work life in their identity construction converge, to a large extent, with the values and beliefs considered important in entrepreneurship (Begley and Boyd 1987; Ginsberg and Buchholtz 1989; Gupta, Turban, and Watsi 2009; McGarth, MacMillan, and Scheinberg 1992). By contrast, the values and beliefs that the non-potential entrepreneurs in our analysis ascribed to work life clearly showed how these individuals positioned themselves as an entrepreneurial "out-group," aligning themselves, instead, with an identity as an employee. 
Our findings reveal how potential entrepreneurs induce entrepreneurship with meaning by reinforcing the positive micro-foundations of becoming an entrepreneur, while non-potential entrepreneurs undermine the same with negative microfoundations. This revealed that, from the potential entrepreneurs' perspective, the ideal conditions for work life involved being free to choose what and how to do their daily work in line with their interests, a preparedness for long work hours and the need to sacrifice spare time, and a willingness to put their new ventures ahead of their personal and family lives based on the conviction (but not the certainty) of achieving extraordinary financial gain (cf. Bird and Jellinek 1988). Individuals who constructed their identities based on these positive beliefs will logically be ready to make the leap to self-employment.

By contrast, non-potential entrepreneurs constructed an identity that distanced them from entrepreneurship. As such, these individuals enforced their counter-position with the importance of well-being in work life, which they considered to conflict with an entrepreneurial lifestyle. They also argued that they could achieve superior compensation from employment and doubted their abilities to access the resources needed to embark on an entrepreneurial journey. The negative aspects of these micro-foundations posited that entrepreneurship involves responsibility, which brings added stress, and potential conflicts with subordinates and other actors and that these negative aspects outweighed the utility derived from the other more pleasurable aspects of being one's own boss.

Our findings add to the entrepreneurship literature by focusing on the currently under-researched dimension of how entrepreneurial and nonentrepreneurial identities are motivated by cognitive beliefs during the preaction phase of the entrepreneurial process. This study addresses this gap by exploring the earliest stage of entrepreneurial activity and how young individuals undertake identity work to achieve legitimacy for themselves and their proposed ventures. Specifically, our study contributes to the literature on potential entrepreneurs, which generally involves a self-belief imbued with notions of who and what an entrepreneur is, and this self-image of being an entrepreneur becomes the foundation of the imagined future venture. Thus, we show that entrepreneurial identity formation is a multifaceted process of enacting beliefs about entrepreneurship to convince oneself that one can become an entrepreneur and that it is largely anchored in the persona of the potential entrepreneur. The identity work needs to fit their sense of who they are, what an entrepreneur should be, and the extent to which these beliefs map onto their self-beliefs regarding the proper career choice. Such insights are pivotal for the potential stages of entrepreneurship (Gartner 1989; Greene, Han, and Marlow 2013; Hoang and Gimeno 2010a, 2010b). As such, our study responds to the call for a deeper understanding of the important cognitive variables on which the personal decision of whether to become an 
entrepreneur depend (e.g. Baron 2004; Shaver and Scott 1991). We show how a cognitive approach to identity formation offers important insights into the complex process of engaging in entrepreneurship (see, e.g. Mitchell et al. 2007).

We demonstrate how individuals construct their reality with regard to engaging in entrepreneurship, which provides behavioural direction and frames young individuals' perceptions of their career choices. Self-beliefs, including perceptions regarding one's own desire to become entrepreneur, one's ability to manage the entrepreneurial role, the availability of critical resources, and the financial consequences of entrepreneurship, appear to motivate (or not) the formation of an entrepreneurial identity, which is linked to the initiation of founding a new venture. By conceptualizing the micro-foundations of an entrepreneurial identity and improving our understanding of how identities are motivationally formed, we contribute with new conceptualizations with which to understanding identity construction. This contributes new knowledge regarding how entrepreneurial identities are formed or not. Similarly, the opposite construction of a non-entrepreneurial identity, as reflected in Figure 1, depicts previously hidden micro-foundations of non-entrepreneurial identity construction, which often go unquestioned. The present research is important, therefore, in outlining how potential and non-potential entrepreneurial identities are cognitively embedded through the socially constructed meaning of entrepreneurship.

Through the social identity lens, we capture the fundamental aspects of an individual's identity that are relevant to career choices, such as becoming an entrepreneur. We therefore show the relevance of social identity theory for understanding entrepreneurial intentions (Hogg and Terry 2000; Tajfel and Turner 1979). Our findings support the notion of social identity theory by showing that an individual's identity serves as a cognitive frame for interpreting experience and that identity work increases intentions to engage in certain actions. Young individuals are more likely to define the situations into which they enter in ways that make their entrepreneurial/non-entrepreneurial identities relevant and strive for actions consistent with these identities (Stets and Burke 2000). Intentions have been found to be critical for emerging businesses, even though the actual launch of a new venture may be relatively unplanned (e.g. it may occur when an unexpected new opportunity emerges). A strong intention to start a business should, therefore, lead to an eventual attempt. However, immediate circumstances (e.g. childbearing, finishing school, or a well-paid or rewarding job) may cause a long delay. This theory can serve as a valuable lens through which to further improve our understanding of the heterogeneity of meanings that young individuals associate with their career choices and potential entrepreneurial endeavors. As previously pinpointed in the literature using the theory of planned behavior, there are strong theoretical and empirical reasons for more research focused on self-identity as an 
additional intention and behavior predictor in the theory of planned behavior framework (Fishbein and Ajzen 2010). Because little has previously been known about self-identity in this framework, this study provides an important contribution to filling this knowledge gap.

With respect to policy and practice, one of the largest future challenges is changing social beliefs about entrepreneurship to encourage young individuals to form entrepreneurial identities. Policies and public measures to promote entrepreneurship and improve access to initial resources are necessary to address this challenge. Effective policy measures may foster positive conditions for entrepreneurship and enable ventures to grow, which will lead to increased growth and employment. Obstacles to embarking on an entrepreneurial journey need to be mapped and addressed to develop effective support mechanisms for growth and innovation, and this research contributes to this body of knowledge. In particular, this study demonstrates that individuals consider risk, independence, income, and their own abilities when constructing their career identities; thus, each of these factors is important for fostering an entrepreneurial identity. When making career choices, an individual expects to gain utility from their choices. This study illuminates how such utility beliefs may push identities to develop in one direction or another. For an entrepreneurial avenue to be a credible option, an individual must perceive the utility of entrepreneurship as desirable. Individuals who highly value entrepreneurship will be more likely to choose such a path during times of transition (e.g. when young individuals are about to enter working life). Therefore, this study has several practical implications. First, it shows that increasing positive identity construction with regard to entrepreneurship among young individuals has value for nations seeking to increase self-employment and become or remain internationally competitive. Policy actors can develop support for such constructions by creating guidelines based on the findings of this study, which provides detailed insights into how individuals form their identities and the micro-foundations at work in such formations that shape their identities and intentions toward entrepreneurial activity. Business education programs need to incorporate elements that enhance the development of an entrepreneurial identity and, in turn, help to foster more entrepreneurs. Policy actors should, therefore, facilitate educational processes that develop more positive entrepreneurial identity work and structures to serve as interfaces with the business community and thus help young people engage in entrepreneurial activity and create the conditions that will encourage young individuals to choose self-employment as a career option. 


\subsection{Limitations and Future Research}

All empirical studies have limitations, and our effort to understand and conceptualize entrepreneurial/non-entrepreneurial identity formation is no exception. Here, we identify some limitations that can serve both as qualifiers for the emergent theory and warrants for further research. Consistent with the guidelines of qualitative research (see Eisenhardt 1989), we suggest exercising caution when evaluating the concepts explored in this paper and encourage further research to build on the framework presented here. Further, we realize that our focus on young individuals - in this case, a selection of Swedish individuals - may limit the generalizability of our findings. Although outside the scope of this research, we acknowledge the possibility of regional and cultural variations and encourage further research (see, e.g. Storhammar and Tohmo 2014). However, we believe that the specific findings acquired - and, especially, the grounded theory - are applicable to individuals in different countries who are about to enter work life and attempting to embark on a career path that will meet their expectations. We also feel that the major concepts of socially constructed identities are relevant to all people in transition. We suggest that future research could enrich the context of the present study by introducing a broader design and incorporating a larger number of individuals in Sweden and elsewhere, including people from different age groups and with different experiences. We believe that an increased focus on these types of studies could produce interesting theoretical knowledge about the various aspects of entrepreneurship. The present study attempts to add to the conceptualization of identity constructions, and we encourage further studies to continue on this path.

\section{Appendix 1: Interview Protocol}

What do you intend to do in your work life?

What is your view of entrepreneurship and running your own business?

How do you reason regarding starting your own business or acquiring an established business? Would you consider doing that? Why/why not?

What would it take for you to/do you consider starting your own business/taking over a business? What are the critical factors/situations in your reasoning?

What do you consider the main advantages and disadvantages of owning and running your own business? Why? 


\section{Appendix 2: Micro-foundations of an Entrepre- neurial Identity}

\begin{tabular}{ll}
\hline Second order & First order \\
\hline Motivational differences relative & Aspire to independence \\
to work-life perceptions - Self- \\
determining
\end{tabular}

Representative statement

"I can decide myself how to conduct my work. That is under my own control. That is also a driving force for me to own my own business."

"No one else will decide for me; I will decide for myself."

"With your own business, you can manage and make decisions the way you like, and you will always have the final say. You could practically do whatever you want." "I don't need to think about satisfying any other manager."

Desire to be in charge - a passion for power

"It just feels more inspiring to be my own boss." "I look forward to a free job where I set my own agenda for the day."

"I will be able to shape my work as I want to."

"There are almost only advantages to starting my own business. Taking charge and deciding everything myself is very appealing." "With my own business, I, as a manager, can manage and make decisions the way I like, and I will always have the final say."

Dreams of achievement - "I want to run my own business; it a passion for appeals to me. I burn for my idea, entrepreneurship and it is my interest. I would not do it otherwise."

"I feel so inspired to follow my dream to run my own business." "I am ready to start my own business. I am interested in product development, so that would be my focus." 
(continued)

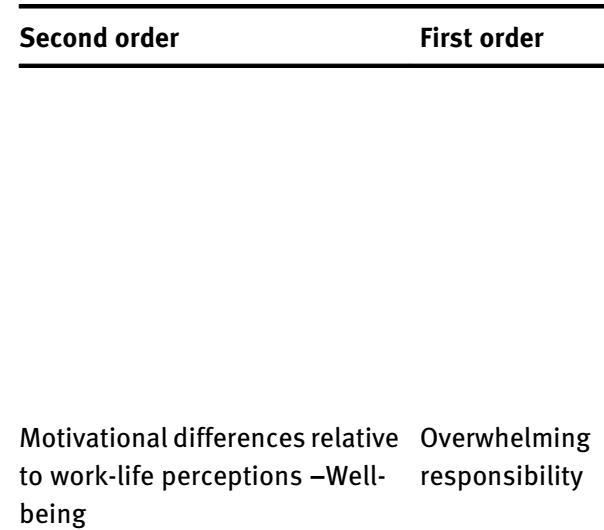

Pressing work effort requiring personal sacrifice

\section{Representative statement}

"Developing products is a dream for me, something I have always been interested in."

"Having the opportunity to develop something that may become a success is a driving force." "The dream is to achieve something, to build it and experience it becoming successful." "It feels like it's too much responsibility. It would simply just be too much ..."

"Being employed will also mean a slower work pace and that I don't need to be responsible for making all the money."

"As an employee, you don't need to feel that extra responsibility that everything should work." "You would have so much to do and a lot of responsibility." "There would be a lot of pressure on you. It could be tough, since everything depends on you." "There is a sick pressure to perform at all times and to keep all the balls in the air, with employees to take care of, financials, and planning." "I want to have energy and time to do what I like to do in my spare time. I believe that this is difficult as an entrepreneur."

"You won't have any time left for anything but work, work, work." "It is a lot of work to have your own business, and it is like work becomes your life. I don't want that." "No normal work hours, really. You need to make sure that everything runs as it should."

"I am not prepared to sacrifice my life for a job. I want a job that allows me to have holidays and not have to think about work all the time." 
(continued)

\begin{tabular}{|c|c|c|}
\hline Second order & First order & Representative statement \\
\hline & $\begin{array}{l}\text { Requirements to do unfa- } \\
\text { miliar or challenging work } \\
\text { tasks }\end{array}$ & $\begin{array}{l}\text { "I will have time to meet with my } \\
\text { friends, but I would have had to } \\
\text { sacrifice that if I started my own } \\
\text { business, and I am not prepared to } \\
\text { do that." } \\
\text { "I think it means a heavy overload } \\
\text { of things to do all the time. I think it } \\
\text { is quite nice to just be employed by } \\
\text { someone else." } \\
\text { "I would be afraid of getting } \\
\text { burned out. I would work too } \\
\text { hard." } \\
\text { "It is not for me: too much work, } \\
\text { and you easily get into deep } \\
\text { water." } \\
\text { "You have to be tough; otherwise, } \\
\text { you will get eaten. [You must] be } \\
\text { able to sack your friends." } \\
\text { "I have heard about entrepreneurs } \\
\text { who had their own businesses who } \\
\text { got burned out, and I don't want to } \\
\text { end up like that. There is too much } \\
\text { pressure involved" } \\
\text { "It is too much to take care of, ac- } \\
\text { counting, economics, and such } \\
\text { things that are not directly related } \\
\text { to the job itself. I want to do what I } \\
\text { am good at, what I am educated to } \\
\text { do, and not a bunch of other } \\
\text { things." } \\
\text { "I don't want to be a boss. I want to } \\
\text { do what I am good at." } \\
\text { "I want to be a mechanic, and if I } \\
\text { have my own business, I will have } \\
\text { to spend my time to manage it. } \\
\text { Then, I won't get to do what I want." }\end{array}$ \\
\hline $\begin{array}{l}\text { Constructing motivational dif- } \\
\text { ferences in expectations for } \\
\text { compensation - "jam } \\
\text { tomorrow" }\end{array}$ & $\begin{array}{l}\text { Superior future personal } \\
\text { compensation }\end{array}$ & $\begin{array}{l}\text { "To earn tremendous amounts of } \\
\text { money is very appealing." } \\
\text { "I can earn a lot of money if I start } \\
\text { my own business." }\end{array}$ \\
\hline
\end{tabular}


(continued)

\begin{tabular}{|c|c|c|}
\hline Second order & First order & Representative statement \\
\hline & Future bonus for hard work & $\begin{array}{l}\text { "I will make a fortune and have a } \\
\text { large reliable customer based, so I } \\
\text { will make a lot of money." } \\
\text { "I would not start a business un- } \\
\text { less I was certain to make money } \\
\text { on it and become rich. You could } \\
\text { get a nice salary, and you have the } \\
\text { power over what will happen." } \\
\text { "I might also get rich doing prod- } \\
\text { uct development in my own } \\
\text { business." } \\
\text { "The opportunity to earn more } \\
\text { money compared to employment is } \\
\text { a driving force for starting a } \\
\text { business." } \\
\text { "I want to become financially in- } \\
\text { dependent; therefore, I will start } \\
\text { my own business and become } \\
\text { rich." } \\
\text { "I might not earn a lot of money } \\
\text { until I have a good product. It may } \\
\text { be a tough job. I will not make } \\
\text { money until the product begins to } \\
\text { sell well." } \\
\text { "My parents and also some of my } \\
\text { teachers say that hard work pays } \\
\text { off and owning your own business } \\
\text { could pay really well." } \\
\text { "The money you make is the bonus } \\
\text { for all the hard work you need to } \\
\text { invest" } \\
\text { "So I will make a lot of money, but it } \\
\text { could mean that I have to work a } \\
\text { lot." } \\
\text { "But if I work a lot, I work for my } \\
\text { own benefit, and all time and effort } \\
\text { are invested for my own sake, so it } \\
\text { is just to go for it." }\end{array}$ \\
\hline $\begin{array}{l}\text { Constructing motivational dif- } \\
\text { ferences in expectations for } \\
\text { compensation - "jam today” }\end{array}$ & $\begin{array}{l}\text { Risks compared to poten- } \\
\text { tial returns }\end{array}$ & $\begin{array}{l}\text { "If you don't have anything else in } \\
\text { life than wanting to work and make } \\
\text { money, then it might be fun, but I } \\
\text { am not like that." }\end{array}$ \\
\hline
\end{tabular}


(continued)

\begin{tabular}{|c|c|c|}
\hline Second order & First order & Representative statement \\
\hline & $\begin{array}{l}\text { Secure superior compen- } \\
\text { sation through } \\
\text { employment }\end{array}$ & $\begin{array}{l}\text { "You will risk falling out with your } \\
\text { friends if you need to sack some- } \\
\text { one because the people you hire } \\
\text { will become your friends, and you } \\
\text { don't want to fall out with your } \\
\text { friends." } \\
\text { "Even if you actually earn a lot of } \\
\text { money running your own business, } \\
\text { it should be worth what you need to } \\
\text { sacrifice." } \\
\text { "Money still can't make you feel } \\
\text { good." } \\
\text { "And you don't know if you will be } \\
\text { able to have a holiday, since you } \\
\text { should be accessible at all times if } \\
\text { something happens; otherwise, } \\
\text { everything may come to a stop, and } \\
\text { you lose money." } \\
\text { "My dad had a business, and he } \\
\text { was never at home and worked like } \\
\text { a maniac. It destroyed my parents' } \\
\text { relationship. We never had any } \\
\text { holidays together. I am not pre- } \\
\text { pared to sacrifice family to run my } \\
\text { own business." } \\
\text { "I know people who have their own } \\
\text { businesses. One of my friend's } \\
\text { mothers works in a shop. She } \\
\text { works } 24 / 7, \text { and she does not get } \\
\text { rich by doing that. It's a going } \\
\text { concern, but nothing more." } \\
\text { "I have seen the downside of } \\
\text { running your own business among } \\
\text { my friends' parents. They work } \\
\text { extremely hard and have no time } \\
\text { for their kids, can barely take some } \\
\text { days off, and do not earn the } \\
\text { amount of money that would } \\
\text { compensate for losing their social } \\
\text { such a situation." }\end{array}$ \\
\hline
\end{tabular}


(continued)

\begin{tabular}{l}
\hline Second order $\quad$ First order \\
\hline \\
Motivational differences relative Stress as manageable \\
to manageable work-life - Self- \\
reliance
\end{tabular}

Representative statement

“I have a friend whose parents own a business with about $100 \mathrm{em}$ ployees, and he has told me how he feels, how much he works, and that terrifies me."

"I want to work for someone else to have time for other things." "It may be stressful, and I might need to work a lot to make my business thrive, but it is worth it, I think, and I can manage it." "I believe I can control that." "I have seen my dad quite stressed sometimes, and that is a possible disadvantage, but it seems like you get to do a lot of fun things too with having your own business. You get to travel and so on."

"When you read newspapers and online about entrepreneurs, it's often about who got burned out or almost worked to death with their businesses. But I try to find something good to read about those who succeed instead of reading

Heavy workload as manageable

Risk of bankruptcy as manageable about those who work to death." "But you can set your own limits and try to do no more than $9 \mathrm{~h}$ per day. But it is not that likely that I will need to have limits." "I prefer not to think about the downsides when it feels like I am about to live my dream to succeed." "I will probably always think about work, and that will likely cost me cognitive effort and risk taking a lot of energy, but I will be able to manage it." "It might go to hell, but it may just as well become a success." "It is important to be realistic too and to consider the consequences." 
(continued)

\begin{tabular}{l}
\hline Second order First order \\
\hline \\
Motivational differences relative Stress as not worth it \\
to manageable work-life - Self- \\
doubt
\end{tabular}

Motivational differences in beliefs relative to resource acquisition abilities -Controllable

\section{Representative statement}

"I want to run my own business because you are not sure to have a job if you work for someone else, either."

"It means a heavy load of work 24/7. I might not be able to have holidays like ordinary people who are employed, and it might be stressful."

"You have to work many more than $8 \mathrm{~h}$ a day, and I think there is a lot of stress to it."

"It is not for me. I think it is too stressful, too much work." "You get pretty stressed out, and it's tough. You might also have difficulties taking leave off. Then, you need to have someone to fill in." "I have heard of entrepreneurs who got burned out, and I don't want to end up like that." "I think it seems to be mostly stressful and an overload of things to do."

Uncontrollable risk of per- "A great risk is that I could not sonal bankruptcy afford the necessary investments, and what if there are no customers, and what about the risks of bankruptcy in the long run?"

"I think that you need to be genuinely interested, and I am not, and the risk of bankruptcy really puts me off. I think it is quite nice to just be employed by someone else." "I could lose everything: go bankrupt!"

Accessible knowledge acquisition "I need knowledge about starting a business and help from others to make it a reality. I will get myself a mentor for that."

"I learn now, and I have learned a lot about accounting, too. I can manage that by myself. I just need to learn how to be a manager." 
(continued)

\begin{tabular}{|c|c|c|}
\hline Second order & First order & Representative statement \\
\hline & Financing as manageable & $\begin{array}{l}\text { "When you start the business, you } \\
\text { need to learn all about it and that it } \\
\text { is just very hard work." } \\
\text { "I just need to learn how to run a } \\
\text { business and how to make it a } \\
\text { success, so I will take a course in } \\
\text { running a business." } \\
\text { "I don't know about financial } \\
\text { management, but I can always take } \\
\text { a course. I don't know how I will be } \\
\text { as a manager, but I can learn that } \\
\text { as well." } \\
\text { "I might have to learn some more } \\
\text { in business administration. I am } \\
\text { planning to take a university } \\
\text { course in business administration. } \\
\text { Otherwise, I don't believe I am } \\
\text { missing anything in particular to } \\
\text { start my business." } \\
\text { "I need this knowledge, but it } \\
\text { should be relatively easy to get it. I } \\
\text { know who to turn to." } \\
\text { "I need start-up capital, and I need } \\
\text { to get money to be able to make my } \\
\text { business a reality." } \\
\text { "I believe in my idea and will try to } \\
\text { get the money that I need. I think I } \\
\text { can get investment money from my } \\
\text { customers; otherwise, I will } \\
\text { consider finding someone else } \\
\text { who can invest in my business and } \\
\text { become part owner of my } \\
\text { business." } \\
\text { "My biggest concern is that I won't } \\
\text { be able to afford to invest time in } \\
\text { product development. How should } \\
\text { I finance that part? But it will work } \\
\text { out; I have time to figure it out." } \\
\text { "It will cost a lot of money, but I } \\
\text { might be able to borrow." } \\
\text { "I cannot have only bank loans, } \\
\text { and paying salary might, from time } \\
\text { to time, be difficult." }\end{array}$ \\
\hline
\end{tabular}


(continued)

\begin{tabular}{ll}
\hline Second order & First order \\
\hline Motivational differences in be- & Lack of access to \\
liefs relative to resource acqui- & knowledge \\
sition abilities -Uncontrollable &
\end{tabular}

Representative statement

"There is a lot that you need to know, so you should have studied business administration in school so that you have learned accounting and other business-related issues. I would have had to learn that, and I am not sure that you could just decide to start your own business without knowing how it works."

"I think I know something about running a business, but far from enough. It would require that I learn a lot about business administration." "I would need more knowledge about starting my own business and how to do it and what happens if you fail."

"I have no idea of how to start a business or how to run it. All that business administration: I don't know that."

"There is a lot that I would have needed to learn, and it is all up to me to learn it. I am fully responsible for managing my learning. I also need to build a good network, and that is not easy. I would not know where to begin."

"I don't think I could do it. It is too much work, and it feels very strange to me."

Self-doubt regarding abil- "It would help to have a lot of ity to access finance money and to have access to a lot of knowledge, such as advice or good personnel, if I need that." "You want to know that you can afford it, that is, to avoid loans. It is the financial aspect that worries me the most. You don't want to risk having to leave your house if you don't succeed." 
(continued)

\begin{tabular}{ll}
\hline Second order & Representative statement \\
\hline & "I would also have to save a lot of \\
money to have something to start & with." \\
"I don't have the money to start a \\
business. It costs a lot, and it is not \\
easy to find the right properties." \\
"I would want to know that I can \\
afford to avoid loans. I don't want \\
to risk having to leave my house if I \\
don't succeed."
\end{tabular}

\section{References}

Ajzen, I. 1987. "Attitudes, Traits, and Actions-Dispositional Prediction of Behavior in Personality and Social-Psychology." Advances in Experimental Social Psychology 20: 1-63.

Ajzen, I. 1991. "The Theory of Planned Behavior." Organizational Behavior and Human Decision Processes 50 (2): 179-211.

Ashforth, B. E., and F. Mael. 1989. "Social Identity Theory and the Organization." Academy of Management Review 14 (1): 20-39.

Autio, E., R. H. Keeley, M. Klofsten, G. G. C. Parker, and M. Hay. 2001. "Entrepreneurial Intent Among Students in Scandinavia and in the USA." Enterprise and Innovation Management Studies 2 (2): 145-60.

Barba-Sánchez, V., and C. Atienza-Sahuquillo. 2017. "Entrepreneurial Motivation and SelfEmployment: Evidence from Expectancy Theory.” International Entrepreneurship and Management Journal 13 (4): 1097-115.

Baron, R. A. 2004. "The Cognitive Perspective: A Valuable Tool for Answering Entrepreneurship's Basic "Why" Questions." Journal of Business Venturing 19 (2): 221-39.

Begley, T. M., and D. P. Boyd. 1987. "Psychological Characteristics Associated with Performance in Entrepreneurial Firms and Smaller Businesses." Journal of Business Venturing 2 (1): 79-93.

Berger, P. L., and T. T. Luckmann. 1966. The Social Construction of Reality: A Treatise in the Sociology of Knowledge. New York: Double and Company.

Beugelsdijk, S. 2007. "Entrepreneurial Culture, Regional Innovativeness and Economic Growth.” Journal of Evolutionary Economics 17 (2): 187-210.

Bird, B. 1988. “Implementing Entrepreneurial Ideas: The Case for Intention." Academy of Management Review 13 (3): 442-53.

Bird, B., and M. Jelinek. 1988. "The Operation of Entrepreneurial Intentions." Entrepreneurship Theory and Practice 13 (2): 21-9.

Cardon, M. S., J. Wincent, J. Singh, and M. Drnovsek. 2009. "The Nature and Experience of Entrepreneurial Passion.” Academy of Management Review 34 (3): 511-32. 
Chandler, G., and D. Lyon. 2001. "Issues of Research Design and Construct Measurements in Entrepreneurship Research: The Past Decade." Entrepreneurship: Theory \& Practice 25: 101-13.

Chroneer, D., J. Johansson, and M. Malmstrom. 2015. "Business Model Management TypologiesCognitive Mapping of Business Model Landscapes." International Journal of Business and Management 10 (3): 67.

Deephouse, D. L., and M. Suchman. 2008. “Legitimacy in Organizational Institutionalism.” The Sage Handbook of Organizational Institutionalism 49: 77.

Dodd, S. D. 2002. “Metaphors and Meaning: A Grounded Cultural Model of US Entrepreneurship." Journal of Business Venturing 17: 519-35.

Douglas, E. J., and D. A. Shepherd. 2000. "Entrepreneurship as a Utility Maximizing Response." Journal of Business Venturing 15 (3): 231-51.

Eisenhardt, K. M. 1989. "Building Theories from Case Study Research." Academy of Management Review 14 (4): 532-50.

Eisenhardt, K. M., and M. E. Graebner. 2007. "Theory Building from Cases: Opportunities and Challenges." Academy of Management Journal 50 (1): 25-32.

Fauchart, E., and M. Gruber. 2011. "Darwinians, Communitarians, and Missionaries: The Role of Founder Identity in Entrepreneurship." Academy of Management Journal 54 (5): 935-57.

Fayolle, A., B. Gailly, and N. Lassas-Clerc. 2006. "Assessing the Impact of Entrepreneurship Education Programmes: A New Methodology." Journal of European Industrial Training 30 (9): 701-20.

Fishbein, M., and I. Ajzen. 2010. Predicting and Changing Behavior: The Reasoned Action Approach. New York: Taylor and Francis Group.

Fisher, G., S. Kotha, and A. Lahiri. 2016. "Changing with the Times: An Integrated View of Identity, Legitimacy, and New Venture Life Cycles.” Academy of Management Review 41 (3): 383-409.

Gabriel, Y. 2000. Storytelling in Organizations: Facts, Fictions, and Fantasies: Facts, Fictions, and Fantasies. UK: OUP Oxford.

Gartner, W. B. 1989. "Who is an Entrepreneur? Is the Wrong Question." Entrepreneurship Theory and Practice 13 (4): 47-68.

Gartner, W. B., K. G. Shaver, E. J. Gatewood, and J. Katz. 1994. "Finding the Entrepreneur in Entrepreneurship." Entrepreneurship Theory and Practice 18 (3): 5-10.

Gifford, S. 1993. "Heterogeneous Ability, Career Choice and Firm Size." Small Business Economics 5 (4): 249-59.

Ginsberg, A., and A. Buchholtz. 1989. “Are Entrepreneurs a Breed Apart-A Look at the Evidence.” Journal of General Management 15 (2): 32-40.

Gioia, D. A., S. D. Patvardhan, A. L. Hamilton, and K. G. Corley. 2013. "Organizational Identity Formation and Change." Academy of Management Annals 7 (1): 123-93.

Glaser, B. G., and A. L. Strauss. 1967. The Discovery of Grounded Theory. Chicago: Aldine.

Global Entrepreneurship Monitor. 2014. Report by S. Singer, J. Amorós, D. Arreola and Global Entrepreneurship Research Association. Also available at https://www.gemconsortium.org/ report/49079.

Greene, F. J., L. Han, and S. Marlow. 2013. "Like Mother, like Daughter? Analyzing Maternal Influences Upon Women's Entrepreneurial Propensity.” Entrepreneurship Theory and Practice 37 (4): 687-711.

Gupta, V. K., D. B. Turban, and S. A. Watsi. 2009. "The Role of Gender Stereotypes in Perceptions of Entrepreneurs and Intentions to Become an Entrepreneur." Entrepreneurship Theory and Practice 33: 397-417. 
Hallen, B. L., and K. M. Eisenhardt. 2012. "Catalyzing Strategies and Efficient Tie Formation: How Entrepreneurial Firms Obtain Investment Ties.” Academy of Management Journal 55 (1): 35-70.

Hoang, H., and J. Gimeno. 2010a. "Becoming an Entrepreneur: A Theory of Entrepreneurial Identity." Journal of Business Venturing 25: 41-53.

Hoang, H., and J. Gimeno. 2010b. "Becoming a Founder: How Founder Role Identity Affects Entrepreneurial Transitions and Persistence in Founding." Journal of Business Venturing 25 (1): 41-53.

Hogg, M. A., and D. J. Terry. 2000. "Social Identity and Self-Categorization Processes in Organizational Contexts." Academy of Management Review 25: 121-40.

Hsu, D. K., R. S. Shinnar, and B. C. Powell. 2014. "Expectancy Theory and Entrepreneurial Motivation: A Longitudinal Examination of the Role of Entrepreneurship Education." Journal of Business and Entrepreneurship 26 (1): 121-40.

Hytti, U., and C. O'Gorman. 2004. "What is "Enterprise Education"? An Analysis of the Objectives and Methods of Enterprise Education Programmes in Four European Countries." Education + Training 46 (1): 11-23.

Ireland, D. R., and J. W. Webb. 2007. "A Cross-Disciplinary Exploration of Entrepreneurship Research.” Journal of Management 33 (6): 891-927.

Karlsson, T., and K. W. Middleton. 2015. "Strategies for Creating New Venture Legitimacy." Industry and Higher Education 29 (6): 469-79.

Kautonen, T., E. T. Tornikoski, and E. Kibler. 2011. "Entrepreneurial Intentions in the Third Age: The Impact of Perceived Age Norms.” Small Business Economics 37 (2): 219-34.

Kickul, J., and J. A. Zaper. 2000. "Untying the Knot: Do Personal and Organizational Determinants Influence Entrepreneurial Intentions?” Journal of Small Business \& Entrepreneurship 15 (3): 57-77.

Kolvereid, L. 1996a. "Organizational Employment versus Self-Employment: Reasons for Career Intentions." Entrepreneurship Theory and Practice 20 (3): 23-31.

Kolvereid, L. 1996b. "Prediction of Employment Status Choice Intentions." Entrepreneurship Theory and Practice 21 (1): 47-57.

Kolvereid, L., and E. Isaksen. 2006. “New Business Start-Up and Subsequent Entry into SelfEmployment." Journal of Business Venturing 21 (6): 866-85.

Krippendorff, K. 2012. Content Analysis: An Introduction to its Methodology. New York: Sage.

Krueger, N. F., and D. V. Brazeal. 1994. "Entrepreneurial Potential and Potential Entrepreneurs." Entrepreneurship Theory and Practice 19 (3): 91-104.

Krueger, N. F., and A. L. Carsrud. 1993. "Entrepreneurial Intentions: Applying the Theory of Planned Behaviour.” Entrepreneurship \& Regional Development 5 (4): 315-30.

Krueger, N. F., M. D. Reilly, and A. L. Carsrud. 2000. “Competing Models of Entrepreneurial Intentions." Journal of Business Venturing 15 (5-6): 411-32.

Kyrö, P., and C. Carrier. 2005. The Dynamics of Learning Entrepreneurship in a Cross-Cultural University Context. Finland: University of Tampere, Faculty of Education, Research Centre for Vocational and Professional Education.

Lee, S. H., and P. K. Wong. 2004. "An Exploratory Study of Technopreneurial Intentions: A Career Anchor Perspective." Journal of Business Venturing 19 (1): 7-28.

Leitch, C. M., and R. T. Harrison. 2016. "Identity, Identity Formation and Identity Work in Entrepreneurship: Conceptual Developments and Empirical Applications." Entrepreneurship \& Regional Development 28 (3-4): 177-90. 
Lent, R. W., S. D. Brown, and G. Hackett. 1994. "Toward a Unifying Social Cognitive Theory of Career and Academic Interest, Choice, and Performance." Journal of Vocational Behavior 45 (1): 79-122.

Liñán, F., and Y. W. Chen. 2009. "Development and Cross-Cultural Application of a Specific Instrument to Measure Entrepreneurial Intentions." Entrepreneurship Theory and Practice 33 (3): 593-617.

Low, K. D., M. Yoon, B. W. Roberts, and J. Rounds. 2005. "The Stability of Vocational Interests from Early Adolescence to Middle Adulthood: A Quantitative Review of Longitudinal Studies." Psychological Bulletin 131 (5): 713.

MacMillan, I., and J. Katz. 1992. "Idiosyncratic Milieus of Entrepreneurship Research: The Need for Comprehensive Theories." Journal of Business Venturing 7: 1-8.

Marlow, S., and M. McAdam. 2015. "Incubation or Induction? Gendered Identity Work in the Context of Technology Business Incubation." Entrepreneurship Theory and Practice 39 (4): 791-816.

McCall, G. J., and J. L. Simmons. 1966. Identities and Interactions. Washington: Free Press.

Mcgrath, R. G., I. C. MacMillan, and S. Scheinberg. 1992. "Elitists, Risk-Takers, and Rugged Individualists-An Exploratory Analysis of Cultural-Differences Between Entrepreneurs and Non-Entrepreneurs." Journal of Business Venturing 7 (2): 115-35.

Mead, G. 1934. Mind, Self, and Society: From the Standpoint of a Social Behaviorist. Chicago: University of Chicago Press.

Mezias, S. J., and M. Scarselletta. 1994. "Resolving Financial Reporting Problems: An Institutional Analysis of the Process." Administrative Science Quarterly 39: 654-78.

Miles, M. B., and A. M. Huberman. 1994. Qualitative Data Analysis: A Sourcebook. Beverly Hills: Sage Publications.

Mitchell, R. K., L. W. Busenitz, B. Bird, C. Marie Gaglio, J. S. McMullen, E. A. Morse, and J. B. Smith. 2007. "The Central Question in Entrepreneurial Cognition Research 2007." Entrepreneurship: Theory and Practice 31 (1): 1-27.

Mumby, D. K., and R. P. Clair. 1997. “Organizational Discourse.” In Discourse as Social Interaction, edited by T. A. van Dijk, 181-205. London/Thousand Oaks: Sage.

Murnieks, C., and E. Mosakowski. 2007a. "Pathways of Passion: Identity Centrality, Passion, and Behavior Among Entrepreneurs." Journal of Management 40 (6): 1583-606.

Murnieks, C., and E. Mosakowski. 2007b. "Who Am: I? Looking Inside the "Entrepreneurial Identity"." In Frontiers of Entrepreneurship Research, Vol. 27, no. 5, Article 5, edited by A. Zacharakis, et al. Babson Park: Babson College. Also available at http://www.babson. edu/entrep/fer/2007FER/cv_p5.html.

Navis, C., and M. A. Glynn. 2011. "Legitimate Distinctiveness and the Entrepreneurial Identity: Influence on Investor Judgments of New Venture Plausibility." Academy of Management Review 36 (3): 479-99.

Obschonka, M., R. K. Silbereisen, U. Cantner, and M. Goethner. 2015. "Entrepreneurial SelfIdentity: Predictors and Effects within the Theory of Planned Behavior Framework." Journal of Business and Psychology 30 (4): 773-94.

Owens, T. J., D. T. Robinson, and L. Smith-Lovin. 2010. “Three Faces of Identity." Annual Review of Sociology 36: 477-99.

Ozgen, E., and R. A. Baron. 2007. "Social Sources of Information in Opportunity Recognition: Effects of Mentors, Industry Networks, and Professional Forums." Journal of Business Venturing 22 (2): 174-92. 
Peterman, N. E., and J. Kennedy. 2003. “Enterprise Education: Influencing Students' Perceptions of Entrepreneurship." Entrepreneurship Theory and Practice 28 (2): 129-44.

Reynolds, P. 1994. The Entrepreneurial Process: Preliminary Explorations in the U. S. Paper at 1st Eurostate International Workshop on Techniques of Enterprise Panels. Luxembourg.

Shane, S., and S. Venkataraman. 2000. "The Promise of Entrepreneurship as a Field of Research." Academy of Management Review 25 (1): 217-26.

Shane, S., E. A. Locke, and C. J. Collins. 2003. "Entrepreneurial Motivation.” Human Resource Management Review 13 (2): 257-79.

Shapero, A., and L. Sokol. 1982. "Social Dimensions of Entrepreneurship.” In Encyclopedia of Entrepreneurship, edited by C. A. Kent, D. L. Sexton, and K. H. Vesper, 72-90. Englewood Cliffs: Prentice Hall.

Shaver, K. G., and L. R. Scott. 1991. "Person, Process, Choice: The Psychology of New Venture Creation." Entrepreneurship Theory and Practice 16 (2): 23-45.

Sheppard, B. H., J. Hartwick, and P. R. Warshaw. 1988. "The Theory of Reasoned Action: A MetaAnalysis of Past Research with Recommendations for Modifications and Future Research." Journal of Consumer Research 15 (3): 325-43.

Stets, J. E., and P. J. Burke. 2000. “Identity Theory and Social Identity Theory." Social Psychology Quarterly 63 (3): 224-37.

Steyaert, C., and J. Katz. 2004. "Reclaiming the Space of Entrepreneurship in Society: Geographical, Discursive and Social Dimensions.” Entrepreneurship \& Regional Development 16 (3): 179-96.

Storhammar, E., and T. Tohmo. 2014. "Innovation Activity of SMEs in Different Locations." International Journal of Innovation and Regional Development 5 (3): 243-65.

Strauss, A., and J. Corbin. 1990. Basics of Qualitative Research, Vol. 15. Newbury Park: Sage.

Suchman, M. C. 1995. “Managing Legitimacy: Strategic and Institutional Approaches." Academy of Management Review 20 (3): 571-610.

Sveningsson, S., and M. Alvesson. 2003. “Managing Managerial Identities: Organizational Fragmentation, Discourse and Identity Struggle." Human Relations 56 (10): 1163-93.

Tajfel, H., and J. C. Turner. 1979. "An Integrative Theory of Intergroup Conflict.” In The Social Psychology of Intergroup Relations, edited by W. G. Austin, and S. Worchel, 33-47. Monterey: Brooks/Cole.

Tajfel, H., and J. C. Turner. 1986. "The Social Identity Theory of Intergroup Behavior." In The Psychology of Intergroup Relations, edited by S. Worchel, and W. G. Austin, 7-24. Washington: Psychology Press.

Thompson, E. R. 2009. "Individual Entrepreneurial Intent: Construct Clarification and Development of an Internationally Reliable Metric." Entrepreneurship Theory and Practice 33 (3): 669-94.

Tohmo, T., and E. Storhammar. 2019. "Innovations and Growth: Evidence from Finnish SMEs." Journal of Enterprising Culture 27 (03): 229-57.

Überbacher, F. 2014. "Legitimation of New Ventures: A Review and Research Programme." Journal of Management Studies 51 (4): 667-98.

Van Gelderen, M., M. Brand, M. van Praag, W. Bodewes, E. Poutsma, and A. Van Gils. 2008. "Explaining Entrepreneurial Intentions by Means of the Theory of Planned Behaviour." Career Development International 13 (6): 538-59.

Veciana, J. M., M. Aponte, and D. Urbano. 2005. “University Students' Attitudes towards Entrepreneurship: A Two Countries Comparison." International Entrepreneurship and Management Journal 1 (2): 165-82. 
Verheul, I., L. Uhlaner, and R. Thurik. 2005. "Business Accomplishments, Gender and Entrepreneurial Self-Image.” Journal of Business Venturing 20: 483-518.

Whetten, D. A., and A. Mackey. 2002. "A Social Actor Conception of Organizational Identity and its Implications for the Study of Organizational Reputation." Business \& Society 41 (4): 393-414.

Ybema, S., D. Yanow, H. Wels, and F. H. Kamsteeg, eds. 2009. Organizational Ethnography: Studying the Complexity of Everyday Life. London: Sage.

Zhao, H., G. E. Hills, and S. E. Siebert. 2005. "The Mediating Role of Self-Efficacy in the Development of Entrepreneurial Intentions.” Journal of Applied Psychology 90 (6): 1265-72. 